\title{
Identification of novel helper epitopes of MAGE-A4 tumour antigen: useful tool for the propagation of ThI cells
}

\author{
T Ohkuri', D Wakita', K Chamoto', Y Togashi, ${ }^{2,3}$, H Kitamura' and T Nishimura ${ }^{*, 1,2}$ \\ 'Division of Immunoregulation, Section of Disease Control, Institute for Genetic Medicine, Hokkaido University, Sapporo, Japan; ${ }^{2}$ Division of ROYCE' \\ Health Bioscience, Institute for Genetic Medicine, Hokkaido University, Sapporo, Japan; ${ }^{3}$ Bioimmulance Co. Ltd, Sapporo, Japan
}

\begin{abstract}
MAGE-A4 has been considered as an attractive cancer-testis (CT) antigen for tumour immunotherapy. It has been well accepted that T-helper type I (ThI) cell-dominant immunity is critical for the successful induction of antitumour immunity in a tumour-bearing host. The adoptive ThI cell therapy has been shown to be an attractive strategy for inducing tumour eradication in mouse systems. However, Th I-cell therapy using human tumour-specific Th I cells, which were expanded from peripheral blood mononuclear cells (PBMCs) in a clinically useful protocol, has never been performed. Here, we first identified MAGE-A4-derived promiscuous helper epitope, peptide (MAGE-A4 280-299), bound to both HLA-DPBI*050I and DRB|**403. Using the peptide, we established a

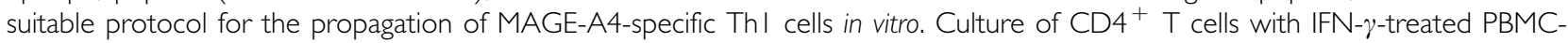
derived adherent cells in the presence of helper epitope peptide resulted in a great expansion of MAGE-A4-reactive Th cells producing IFN- $\gamma$, but not IL-4. Moreover, it was shown that ligation of MAGE-A4-reactive Th I cells with the cognate peptide caused the production of IFN- $\gamma$ and IL-2. Thus, our identified MAGE-A4 helper epitope peptide will become a good tool for the propagation of tumour-specific ThI cells applicable to adoptive immunotherapy of human cancer.

British Journal of Cancer (2009) I 00, I|35- | |43. doi:I0.1038/sj.bjc.6604966 www.bjcancer.com
\end{abstract}

Published online 10 March 2009

(c) 2009 Cancer Research UK

Keywords: helper epitope; promiscuous peptide; tumour-specific CD4 ${ }^{+} \mathrm{T}$ cells; adoptive Th I-cell therapy

Cancer-testis (CT) antigens can be classified into several super families. MAGE gene group is one of the well-characterised members of the CT antigen family that includes six subfamilies, MAGE-A, MAGE-B, MAGE-C, MAGE-D, MAGE-E and MAGE-F. All of these genes are located on chromosome $X$. Among these, MAGE-A, MAGE-B and MAGE-C show expression patterns as CT antigens (Van der Bruggen et al, 1991; De Plaen et al, 1994; Chomez et al, 2001). The expression of MAGE-A4 antigen in tumour has been reported in various human malignancies, ovarian neoplasms (Yakirevich et al, 2003), mucosal melanomas of the head and neck (Prasad et al, 2004), oesophageal adenocarcinomas (Lin et al, 2004), colorectal cancer (Li et al, 2005) and lung cancer (Tajima et al, 2003). Therefore, MAGE-A4 is one of the attractive target molecules in tumour immunotherapy.

Previously, we have proposed that tumour-specific $\mathrm{CD}^{+}$ $\mathrm{T}$ cells, especially T-helper type 1 (Th1) cells play a critical role for inducing cytotoxic T lymphocytes (CTL)-mediated antitumour immunity in tumour-bearing mice (Nishimura et al, 1999; Ikeda et al, 2004; Chamoto et al, 2006; Zhang et al, 2006). Although many investigators have centred in the activation and targeting of tumour-specific $\mathrm{CD} 8{ }^{+} \mathrm{CTL}$ and $\mathrm{CD} 4{ }^{+} \mathrm{T}$ cells are required for the

*Correspondence: Professor T Nishimura, Division of Immunoregulation, Section of Disease Control, Institute for Genetic Medicine, Hokkaido University NI 5 W7, kita-ku, Sapporo 060-08 I5, Japan;

E-mail: tak24@igm.hokudai.ac.jp

Received 25 November 2009; revised 23 January 2009; accepted 10 February 2009; published online 10 March 2009 priming and maintenance of $\mathrm{CD}^{+} \mathrm{T}$ cells (Janssen et al, 2003; Smith et al, 2004; Sun et al, 2004). CD4 ${ }^{+}$T cells stimulate $\mathrm{CD}^{+} \mathrm{T}$ cells through activating antigen-presenting cells (APCs), such as dendritic cells (DCs) through CD40-CD154 interaction (Bennett et al, 1998; Schoenbergner et al, 1998). It was also reported that $\mathrm{CD} 4{ }^{+} \mathrm{T}$ cells could stimulate $\mathrm{CD} 8{ }^{+} \mathrm{T}$ cells by their cell-cell communication through cytokines or the direct cell-tocell interaction (Lu et al, 2000; Giuntoli et al, 2002). Therefore, fully activated tumour-specific $\mathrm{CD}^{+} \mathrm{T}$ cells are important for inducing an effective immunotherapy of the tumour-bearing hosts. For this purpose, many helper epitope peptides have been identified from various tumour antigens (Kobayashi and Celis, 2008). However, there are no reports about helper epitope peptides in MAGE-A4 molecules though several CTL epitopes have been identified (Zhang et al, 2002; Miyahara et al, 2005). Thus, we planned to identify MAGE-A4-derived helper peptide, which will become a great tool for MAGE-A4-targeted immunotherapy.

Adoptive T-cell therapy is one of the most attractive strategies for inducing tumour eradication. Adoptive immunotherapy using tumour-specific $\mathrm{CD}^{+}{ }^{+} \mathrm{T}$ cells isolated from resected tumour tissue was carried out for long terms, but no good clinical responses were obtained from these studies (Dudley et al, 2001, 2002b). However, recently, adoptive cell transfer of $\mathrm{CD} 8{ }^{+} \mathrm{T}$ cells contaminated with $\mathrm{CD}^{+}{ }^{+} \mathrm{T}$ cells into lymphodepleting tumour-patients caused a great inhibition of tumour growth (Dudley et al, 2002a, 2005). In that therapy, the investigators reported that the existence of $\mathrm{CD} 4{ }^{+}$ $\mathrm{T}$ cells appeared to be important for inducing an efficient therapeutic effect. Moreover, it was shown that adoptive cell transfer of NY-ESO-1-reactive $\mathrm{CD}^{+} \mathrm{T}$ cells into melanoma 
patient resulted in a great inhibition of the growth of metastatic tumour tissue (Hunder et al, 2008). We initially showed the crucial role of tumour-specific Th1 cells and the cell transfer of tumourspecific Th1 cells induced tumour-specific CTL in vivo to eradicate the established tumour mass (Nishimura et al, 1999; Chamoto et al, 2003). This result raised the possibility that Th1 cell therapy will become a good strategy for the treatment of human cancer.

Here, we identified new MAGE-A4-derived helper peptides efficiently presented by APC. The one of the peptides binds to both $\mathrm{HLA}-\mathrm{DPB} 1^{\star} 0501$ and $\mathrm{DRB} 1^{\star} 1403$, indicating that it is a promiscuous peptide. Using the peptide, we established a suitable protocol for the propagation of MAGE-A4-specific CD4 ${ }^{+} \mathrm{T}$ cells applicable to adoptive Th1-cell therapy of human cancer. Moreover, we showed that helper epitope peptide is a good tool for the activation of MAGE-A4-specific Th1 cells to produce Th1 cytokines, which will preferable to activate CTL-mediated antitumour immunity. Thus, we believe that our identified MAGEA4-specific CD4-helper epitope peptides will become a good tool for the application to the therapy of human cancer.

\section{MATERIALS AND METHODS}

\section{Cell lines and culture medium}

Epstein-Barr virus-transformed B cells (EBV-B) were generated from peripheral blood mononuclear cells (PBMCs) of healthy volunteers by culturing with culture supernatant from the EBVproducing B95-8 cell line after obtaining written informed consent approved by medical ethics committees of Hokkaido University Graduate School of Medicine. These cells were maintained in RPMI 1640 (Sigma, St Louis, MO, USA) containing 10\% heat-inactivated foetal bovine serum (Life Technologies Inc., Invitrogen, Carlsbad, CA, USA) with $2 \mathrm{~mm}$ L-glutamine, $0.05 \mathrm{~mm}$ 2-mercaptoethanol (Sigma), $10 \mathrm{~mm}$ HEPES, $100 \mathrm{U} \mathrm{ml}^{-1}$ penicillin, and $100 \mu \mathrm{g} \mathrm{ml}^{-1}$ streptomycin sulphate. Dendritic cells (DC) and $\mathrm{T}$ cells were derived from PBMC of healthy volunteers after obtaining written informed consent. Dendritic cells were cultured in AIM-V (Life Technologies) medium without serum. $\mathrm{T}$ cells were cultured in AIM-V medium containing $5 \%$ heat-inactivated pooled human $\mathrm{AB}$ serum (kindly donated from Hokkaido red cross blood centre) or $5 \%$ heat-inactivated foetal bovine serum (Life Technologies).

\section{Peptides, recombinant protein}

Synthetic peptides (purity $>95 \%$ ) were purchased from Greiner BioOne (Tokyo, Japan). MAGE-A4 overlapping peptides were purchased from SIGMA genosys (Hokkaido, Japan). The 44 overlapping peptides covering whole amino-acid sequence of MAGE-A4 were synthesised and designated as M1-M44 peptide (M1-M43: 20-mer peptide, M44: 17-mer peptide). For the initial screening assay, these 44 peptides were subdivided into MIX1-MIX9 peptides pools (MIX1; M1-M5, MIX2; M6-M10, MIX3; M11-M15, MIX4; M16-M20, MIX5; M21-M25, MIX6; M26-M30, MIX7; M31-M35, MIX8; M36-M40, and MIX9; and M41-M44). Recombinant MAGE-A4 protein was expressed in Escherichia coli as full-length protein.

\section{Preparation of PBMC-derived dendritic cells as antigen-presenting cells}

Peripheral blood mononuclear cells from healthy volunteers were isolated by Ficoll-Paque (Amersham Bioscience, Uppsala, Sweden) gradient centrifugation. Peripheral blood mononuclear cells were incubated in 6-well plate (Nalge Nunc International, Roskilde, Denmark) in AIM-V medium without serum. Non-adherent cells were removed and adherent cells were cultured in the presence of GM-CSF (30 $\mathrm{ng} \mathrm{ml}^{-1}$; KIRIN, Tokyo, Japan) and IL-3 (30 $\mathrm{ng} \mathrm{ml}^{-1}$; KIRIN) in AIM-V (Sato et al, 1999; Buelens et al, 2002). Medium was exchanged with fresh medium containing GM-CSF and IL-3 on days 3. On day 7, the adherent DCs were harvested with trypsine (Sigma) and used as APC. The expression of CD11c was $>99 \%$ for these DCs (data not shown).

\section{In vitro stimulation of helper $\mathrm{T}$ cells with recombinant protein-pulsed DC}

$\mathrm{CD}^{+} \mathrm{T}$ cells were purified from PBMC by EasySep CD4 T-cell positive selection kit (Veritas, Tokyo, Japan). Dendritic cells, which were generated from adherent PBMCs by culture with GM-CSF, and IL-3 in vitro were pulsed with $50 \mu \mathrm{g} \mathrm{ml}^{-1}$ rMAGE-A4 protein for $2 \mathrm{~h}$. CD4 ${ }^{+} \mathrm{T}$ cells $\left(1 \times 10^{6}\right)$ were stimulated with autologous mitomycin C (MMC)-treated antigen-pulsed DC $\left(1 \times 10^{5}\right)$ in 24-well culture plate (BD Biosciences, San Jose, CA, USA) in AIM-V medium supplemented with $5 \%$ human AB serum. Seven days later, the stimulated $\mathrm{CD}^{+}{ }^{+} \mathrm{T}$ cells were restimulated with MMC-treated autologous DC pulsed with rMAGE-A4 protein $\left(50 \mu \mathrm{g} \mathrm{ml}^{-1}\right)$. Two days after the secondary stimulation with antigen, human recombinant IL-2 (kindly supplied by Shionogi Pharmaceutical Institute Co. Ltd, Osaka, Japan) was added at a final concentration of $10 \mathrm{IU} \mathrm{ml}^{-1}$. One week later, the $\mathrm{T}$ cells were divided into nine cultures, and each culture was stimulated with PBMC pulsed with peptides mixture (MIX1-MIX9), including MAGE-A4-derived overlapping peptides. After stimulation with peptides mixture, the T-cell cultures were tested for their cytokine production in response to peptides mixture. The $\mathrm{T}$ cells showing a specific response to the cognate mixture were expanded and used for further analysis.

\section{Antigen-specific cytokine production of $\mathrm{T}$ cells}

$\mathrm{T}$ cells $\left(3 \times 10^{4}\right.$ per well $)$ were cultured with or without MMCtreated autologous PBMC $\left(3 \times 10^{4}\right.$ per well) or EBV-B cells $\left(1 \times 10^{4}\right.$ per well) in the presence of relevant antigen in 96-well culture plate (BD Biosciences). After $20 \mathrm{~h}$, culture supernatants were collected and cytokine (IFN- $\gamma$, IL-4, or IL-2) level was measured by ELISA kit (BD Biosciences). Major histocompatibility complex (MHC)restriction was determined by adding anti-HLA-DR monoclonal antibody (mAb) (L243; BD Bioscience), anti-HLA-DP $\mathrm{mAb}$ (BRAFB6), or anti-HLA-DQ mAb (SPV-L3; Serotech Ltd, Raleigh, $\mathrm{NC}$, USA). All mAbs were used at a final concentration of $5 \mu \mathrm{g} \mathrm{ml}^{-1}$.

\section{Establishment of the protocol for the induction of MAGE-A4-specific Th cells useful for clinical therapy}

Isolated PBMC was incubated in 24-well culture plate in serum-free AIM-V medium with $20 \mathrm{ng} \mathrm{ml}^{-1}$ IFN- $\gamma$ (PeproTech, Inc, Rocky Hill, NJ, USA). After $2 \mathrm{~h}$, the adherent PBMCs were treated with MMC. The isolated CD4 ${ }^{+}$T cells were cultured with IFN- $\gamma$-treated PBMC in the presence of MAGE-A4 peptide $\left(10 \mu \mathrm{g} \mathrm{ml}^{-1}\right)$. Seven days later, the cultured $\mathrm{CD}^{+}{ }^{+} \mathrm{T}$ cells were restimulated with IFN- $\gamma$-treated adherent cells derived from PBMC. Further seven days later, peptide-pulsed PBMCs were used as APC to expand peptide-specific Th cells. The expression of cell surface markers of IFN- $\gamma$-treated PBMC was determined by staining with fluoresceinisothiocyanate (FITC)-conjugated mouse anti-HLA-A/B/C mAb, FITC-conjugated mouse anti-HLA-DR/DP/DQ mAb, FITC-conjugated mouse anti-human CD86 mAb, or FITC-conjugated mouse isotype control $\mathrm{mAb}$ ( $\mathrm{BD}$ Biosciences). The cell-associated fluorescence was determined by a multicolour flow cytometer (FACSCalibar, BD Biosciences) and analysed with a computer software (CellQuest, BD Biosciences).

\section{Measurement of cytokine production by Intracellular staining assay}

The cultured Th cells were stimulated with autologous EBV-B cell lines in the presence of cognate or irrelevant peptide, respectively. 
After the 2-h incubation, brefeldin-A (Sigma) was added to the samples and the cells were incubated for an additional $4 \mathrm{~h}$. The intracellular cytokine levels of the cells were determined by staining with R-phycoerythrin (PE)/cyanine-conjugated mouse anti-human $\mathrm{CD} 4 \mathrm{mAb}$ and $\mathrm{PE}$-conjugated mouse anti-human IL- $4 \mathrm{mAb}$ and FITC-conjugated mouse anti-human IFN- $\gamma$ mAb or PE-conjugated mouse anti-human $\mathrm{CD} 8 \mathrm{mAb}$. These antibodies were purchased from BD Biosciences. The cell-associated fluorescence was determined by a multicolour flow cytometer (FACSCalibar, BD Biosciences) and analysed with a computer software (CellQuest, BD Biosciences).

\section{RESULTS}

\section{Identification of MAGE-A4-derived helper epitopes}

To identify MAGE-A4-derived helper epitopes, purified CD4 ${ }^{+}$ $\mathrm{T}$ cells from two healthy donors were stimulated with autologous monocyte-derived DC pulsed with rMAGE-A4 protein. Then, specific responses of the cultured $\mathrm{CD}^{+}{ }^{+}$Th cells to MAGEA4-derived peptide were examined in ELISA. In donor 1, one Th cell line produced significant IFN- $\gamma$ against autologous PBMCs pulsed with mixture of MAGE-A4-derived overlapping peptide. Moreover, it was shown that Th cells produced IFN- $\gamma$ in response to M38 peptide included in MIX8 (Figure 1A). To elucidate HLArestriction of the Th cell line, we used mAb against HLA-DP, HLADQ and HLA-DR. The IFN- $\gamma$ production of Th cell line against M38 peptide was significantly reduced when $M A b$ against HLA-DR was added, whereas mAbs against HLA-DP or HLA-DQ had no effect (Figure 1B). To further analyse the HLA-restriction, we tested the reactivity of Th cells against a range of peptide-pulsed allogeneic EBV-B cell lines with known HLA-DR genotypes. As shown in Figure $1 \mathrm{C}$, the Th cells recognised only HLA-DRB $1{ }^{*} 0101$-expressing EBV-B cell lines, suggested that this M38 peptide was presented by HLA-DRB1*0101.

$\mathrm{CD}^{+}{ }^{+}$Th cells derived from donor 2 revealed the specific IFN- $\gamma$ production in response to autologous PBMC pulsed with M41 peptide (MAGE-A4; AETSYVKVLEHVVRVNARVR) in MIX9. The response was reduced in the presence of anti-HLA-DP $\mathrm{mAb}$, but not HLA-DQ nor HLA-DR (Figure 2B). The Th cells recognised only HLA-DPB ${ }^{\star} 0501$-expressing EBV-B cell lines pulsed with the M41 peptide, suggested that the M41 peptide was presented by HLA-DPB $1^{\star} 0501$ (Figure 2C). As this allele is expressed in more than half of the numbers of Japanese, the M41 peptide is very useful to generate MAGE-A4-specific helper $\mathrm{T}$ cells from many patients. Moreover, M41 peptide-specific Th cell line was also obtained from donor 3 (Figure 3A). Unlike the case of the donor 2, this recognition of the $\mathrm{CD} 4{ }^{+} \mathrm{T}$ cells was inhibited by anti-HLA-DR $\mathrm{mAb}$ (Figure 3B). Because HLA-DR genotypes of donor 3 are DRB $1{ }^{\star} 0401$ and $\mathrm{DRB} 1{ }^{\star} 1403$, we attempted to use allogeneic EBV-B cell lines expressing matched genotype. However, we failed to find any $\mathrm{DRB} 1^{\star} 1403$-expressing cell lines. Therefore, we used DRB1 ${ }^{\star} 1405$-expressing cell lines instead of the DRB ${ }^{\star} 1403$-cell lines. Consequently, the donor 3 -derived Th cells showed a specific reaction to M41 peptide against only autologous cell line, but not DRB $1^{\star} 0401$-expressing allogeneic cell lines (Figure $3 \mathrm{C}$ ). Thus, the M41 peptide has capability of binding to HLA-DRB1*1403, suggesting that the M41 peptide is promiscuous and would be available with tumour immunotherapy. Therefore, we focused on this peptide in the further experiments.

\section{Identifying minimal epitopes of MAGE-A4 recognised by the $\mathrm{CD}^{+}{ }^{+} \mathrm{T}$-cell lines}

To identify MAGE-A4 minimal epitopes recognised by M41specific $\mathrm{CD} 4{ }^{+}$T-cell lines from donor 2 and donor 3 , respectively, a series of 15-mer overlapping peptides derived from M41 peptide
A

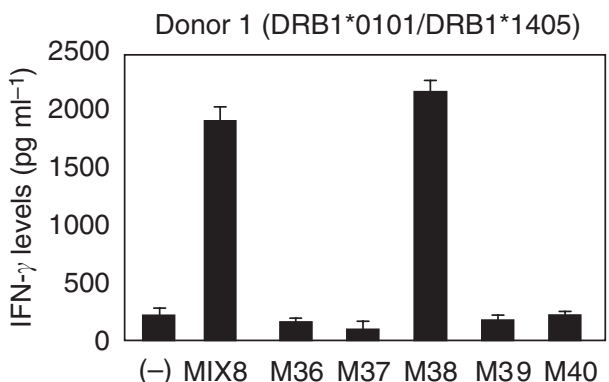

B

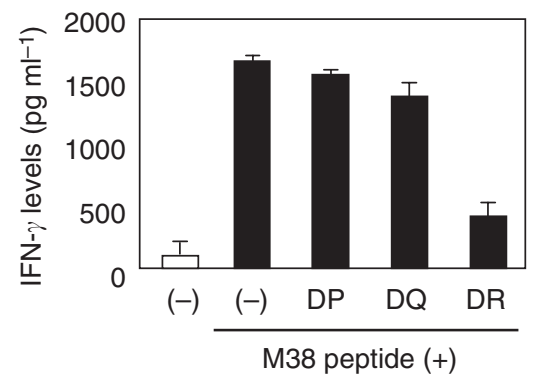

C

HLA of APC

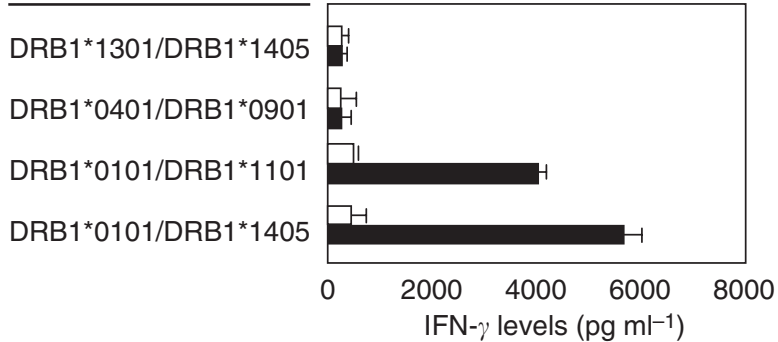

Figure I Induction of HLA-DRBI*0IOI-restricted MAGE-A4-specific $\mathrm{CD}^{+}{ }^{+} \mathrm{T}$ cells from donor I. (A) Donor I-derived CD4 ${ }^{+} \mathrm{T}$ cells were assessed the specificity to overlapping peptides and their mixture, MIX8. The CD4 ${ }^{+} \mathrm{T}$ cells were stimulated with autologous PBMC alone $(-)$ or PBMC pulsed with MIX8 $\left(10 \mu \mathrm{g} \mathrm{m}^{-1}\right)$ or with each of overlapping peptide in the MIX8 $\left(10 \mu \mathrm{g} \mathrm{ml}^{-1}\right)$. HLA types of the donors were displayed over the panel. (B) M38-specific Th cells were stimulated with autologous PBMC pulsed with irrelevant (open bar) or cognate (filled bar) peptide in the presence of $5 \mu \mathrm{g} \mathrm{ml}{ }^{-1}$ of mAbs against HLA-DP, HLA-DQ or HLA-DR. (C) M38-specific Th cells were stimulated with allogeneic EBV-B cell lines pulsed with irrelevant (open bar) or cognate (filled bar) peptide. All T-cell cultures were incubated with the MMC-treated target cells in duplicate for $20-24 \mathrm{~h}$, then the culture supernatants were assessed for IFN- $\gamma$ levels in ELISA. These experiments were carried out independently at least three times. Data denote mean \pm s.e.m. and are representative of the experiments.

were prepared and tested for their ability to stimulate IFN- $\gamma$ release from the both $\mathrm{T}$-cell lines. As shown in Figure 4, the HLA-DPB1 ${ }^{\star} 0501$-restricted CD4 ${ }^{+} \mathrm{T}$ cells recognised EBV-B cells in the presence of $\mathrm{p} 4$ to $\mathrm{p} 9$ peptides, suggesting that this minimal region was MAGE-A4 284-293 (YVKVLEHVVR; Figure 4, left panel). In contrast, the HLA-DRB1 ${ }^{\star} 1403$-restrected CD ${ }^{+} \mathrm{T}$ cells recognised EBV-B cells in the presence of $\mathrm{p} 5$ to $\mathrm{p} 9$ peptides, suggesting that this minimal region was MAGE-A4 284-294 (YVKVLEHVVRV; Figure 4, right panel). Thus, there was a little difference in the epitope recognised by two $\mathrm{CD} 4{ }^{+} \mathrm{T}$-cell lines.

\section{Generation of MAGE-A4-specific $\mathrm{CD}^{+}{ }^{+} \mathrm{T}$ cells by using a synthetic peptide}

We assessed whether a synthetic M41 peptide is able to generate MAGE-A4-specific CD4 ${ }^{+} \mathrm{T}$ cells. $\mathrm{CD} 4{ }^{+} \mathrm{T}$ cells derived from a 
A

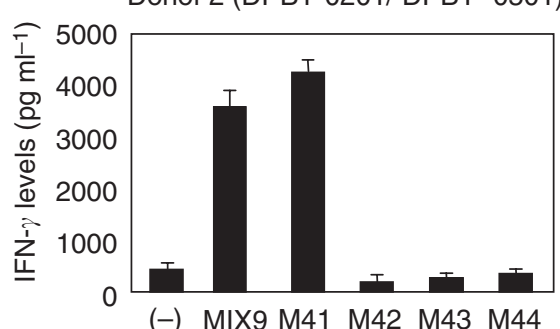

B

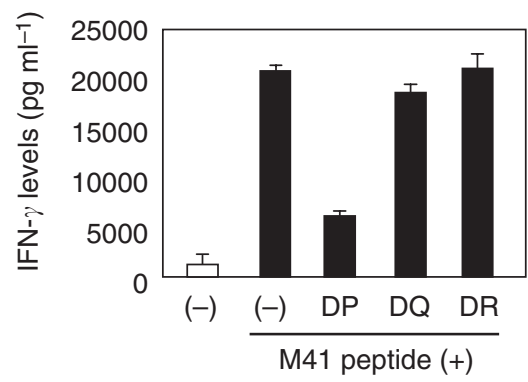

C HLA of APC

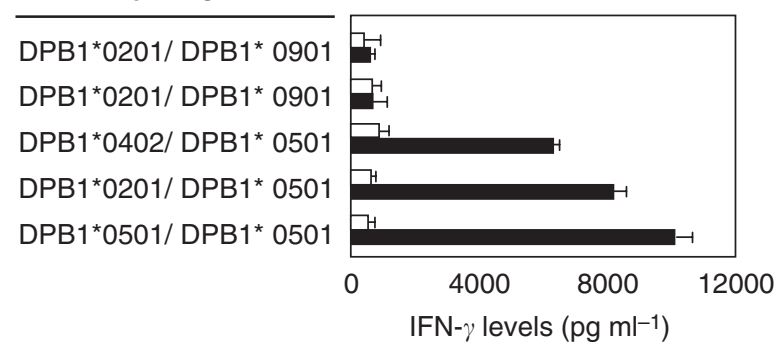

Figure 2 Induction of HLA-DPB|*050I-restricted MAGE-A4-specific $\mathrm{CD}^{+}{ }^{+} \mathrm{T}$ cells from donor 2. (A) Donor 2-derived CD4 ${ }^{+} \mathrm{T}$ cells were assessed the specificity to overlapping peptides and their mixture, MIX9. The CD4 ${ }^{+} \mathrm{T}$ cells were stimulated with autologous PBMC alone $(-)$ or PBMC pulsed with MIX9 $\left(10 \mu \mathrm{g} \mathrm{ml^{-1 }}\right)$ or with each of overlapping peptide in the MIX9 $\left(10 \mu \mathrm{g} \mathrm{ml}^{-1}\right)$. HLA types of the donor were displayed over the panel. (B) M4I-specific Th cells were stimulated with autologous PBMC pulsed with irrelevant (open bar) or cognate (filled bar) peptide in the presence of $5 \mu \mathrm{g} \mathrm{ml}^{-1}$ of mAbs against HLA-DP, HLA-DQ or HLA-DR. (C) M4I-specific Th cells were stimulated with allogeneic EBV-B cell lines pulsed with irrelevant (open bar) or cognate (filled bar) peptide. All T-cell cultures were incubated with the MMC-treated target cells in duplicate for $20-24 \mathrm{~h}$, then the culture supernatants were assessed for IFN- $\gamma$ levels in ELISA. These experiments were carried out independently at least three times. Data denote mean \pm s.e.m. and are representative of the experiments.

donor 4 with HLA-DPB $1^{\star} 0501$ were stimulated with their autologous monocyte-derived DC pulsed with a synthetic M41 peptide. As a result of repetitive stimulation with the peptide, the $\mathrm{CD}^{+}{ }^{+} \mathrm{T}$ cells produced IFN- $\gamma$ in response to the M41 peptide bound to HLA-DPB $1^{\star} 0501$ molecule in APC (Figure $5 \mathrm{~A}$ and $\mathrm{B}$ ), indicating that the synthetic M41 peptide is able to induce MAGEA4-specific $\mathrm{CD}^{+}{ }^{+} \mathrm{T}$ cells effectively.

\section{Development of a protocol for the inducing and propagating peptide-specific Th1 cells applicable to adaptive immunotherapy}

To apply our identified helper epitope peptide to the clinical trial of Th1-cell therapy, we tried to establish a protocol for the induction and propagation of MAGE-A4 peptide-specific Th1 cells useful for Th1 cell therapy. In general, monocyte-derived DC
A

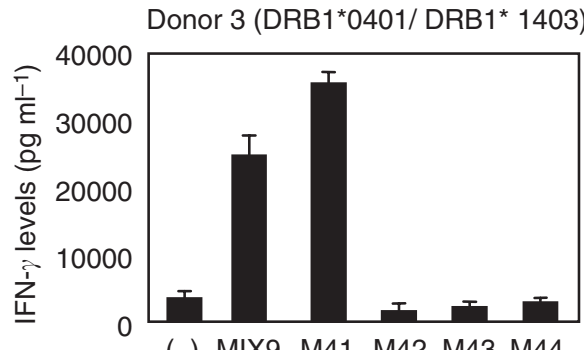

B

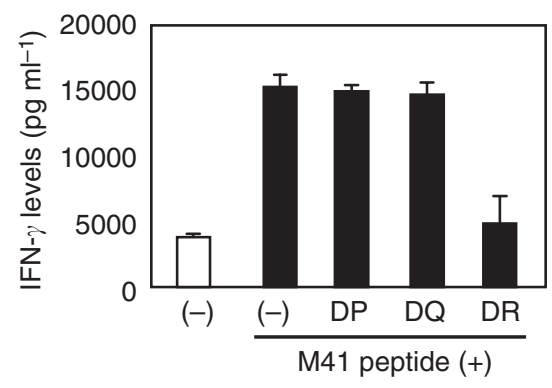

C HLA of APC

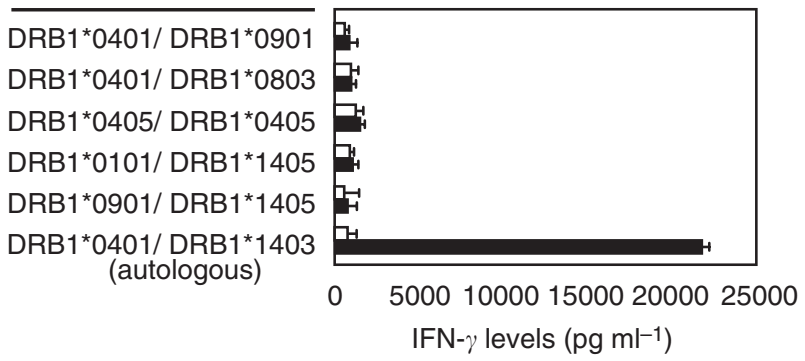

Figure 3 Induction of HLA-DRB|*|403-restricted MAGE-A4-specific $\mathrm{CD}^{+}{ }^{+} \mathrm{T}$ cells from donor 3. (A) Donor 3 -derived $\mathrm{CD} 4^{+} \mathrm{T}$ cells were assessed the specificity to overlapping peptides and their mixture, MIX9. The $\mathrm{CD}^{+}{ }^{+} \mathrm{T}$ cells were stimulated with autologous PBMC alone $(-)$ or PBMC pulsed with MIX9 $\left(10 \mu \mathrm{g} \mathrm{ml}^{-1}\right)$ or with each of overlapping peptide in the MIX9 $\left(10 \mu \mathrm{g} \mathrm{ml}^{-1}\right)$. HLA types of the donor were displayed over the panel. (B) M4I-specific Th cells were stimulated with autologous PBMCs pulsed with irrelevant (open bar) or cognate (filled bar) peptide in the presence of $5 \mu \mathrm{g} \mathrm{ml}^{-1}$ of mAbs against HLA-DP, HLA-DQ or HLA-DR. (C) M4I-specific Th cells were stimulated with allogeneic or autologous EBV-B cell lines pulsed with irrelevant (open bar) or cognate (filled bar) peptide. All T-cell cultures were incubated with the MMC-treated target cells in duplicate for $20-24 \mathrm{~h}$, then the culture supernatants were assessed for IFN- $\gamma$ levels in ELISA. These experiments were carried out independently at least three times. Data denote mean \pm s.e.m. and are representative of the experiments.

expanded in vitro are used as APC for stimulating $\mathrm{T}$ cells with peptide. However, it takes approximately 7 days to prepare DC from PBMC. Therefore, we developed an alternative method. We used freshly isolated PBMC-derived adherent cells as a source of APC. The detailed protocol for preparing APC was shown in Figure 6A. IFN- $\gamma$-treated adherent cells upregulated its expression of HLA-class I, HLA-class II and CD86, respectively, compared with freshly isolated adherent cells (Figure 6B). As shown in Table 1, the same results were obtained in two donors. Thus, we evaluated whether IFN- $\gamma$-treated adherent cells derived from PBMC had a capability of initiating peptide-induced stimulation for enhancing the propagation of MAGE-A4 peptide-specific Th1 cells. CD4 ${ }^{+}$T cells from PBMC of donor 4 and donor 5 were primed by each autologous APC in the presence of M41 peptide. As shown in Figure 7A, peptide-specific CD4 ${ }^{+} \mathrm{T}$ cells were generated more efficiently when IFN- $\gamma$-treated adherent cells were used as 


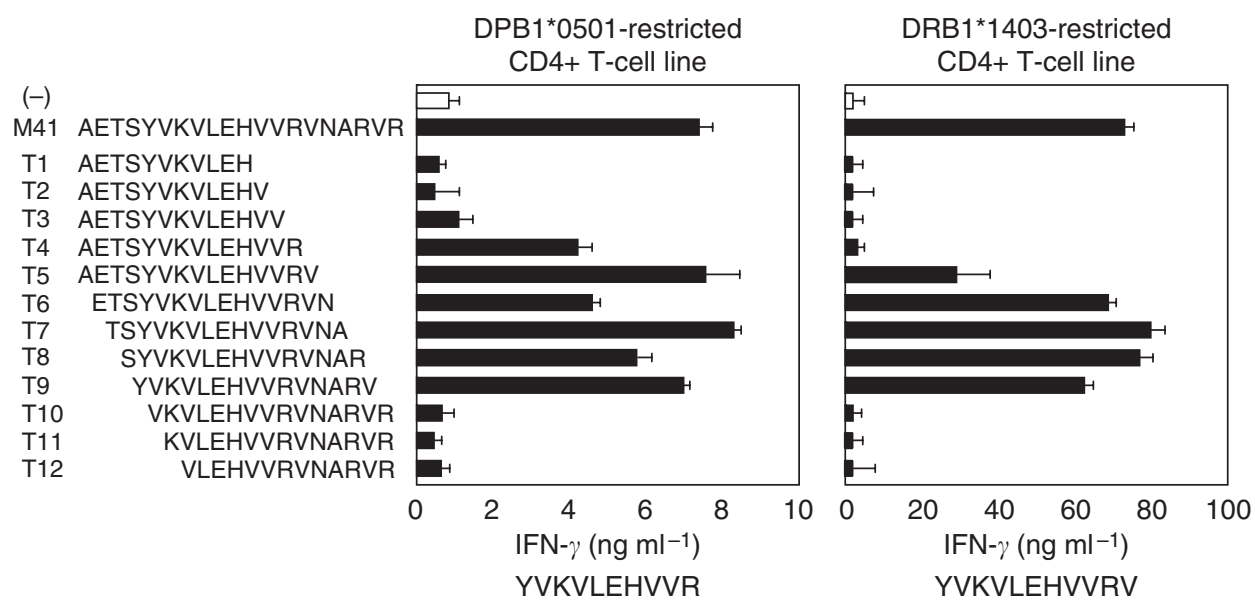

Figure 4 Identification of minimal epitopes recognised by two M4I peptide-specific CD4 ${ }^{+}{ }^{T}$-cell lines. Two M4I peptide-specific CD4 ${ }^{+} \mathrm{T}_{\text {-cell }}$ lines derived from donors 2 and 3 were cultured with their autologous PBMCs pulsed with a series of I5-mer overlapping peptides encompassing M4I peptide (MAGE-A4 280-299). The left panel showed reactivity of HLA-DRBI*050I-restricted CD4 ${ }^{+}$T-cell lines and the right panel showed HLA-DRBI*I403$\mathrm{CD}^{+}{ }^{+} \mathrm{T}$-cell lines. Each minimal epitope of two cell lines were displayed under their graphs. Each T-cell line was stimulated with the MMC-treated target cells pulsed with the indicated peptide $\left(\left.10 \mu \mathrm{g} \mathrm{m}\right|^{-1}\right)$ in duplicate for $20 \mathrm{~h}$, then the culture supernatants were assessed for IFN- $\gamma$ levels in ELISA. These experiments were carried out independently at least three times. Data denote mean \pm s.e.m. and are representative of the experiments.

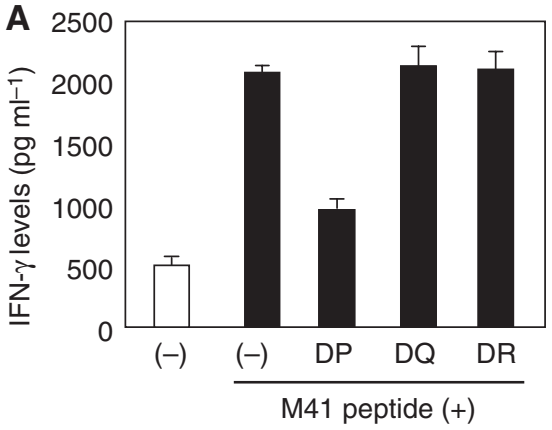

B

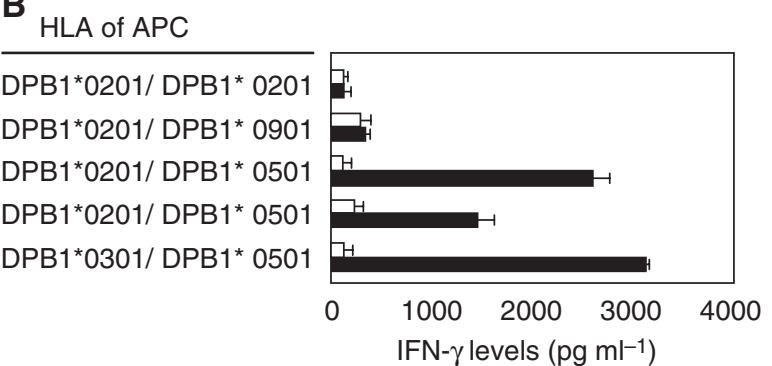

Figure 5 Induction of HLA-DPBI*050I-restricted MAGE-A4-specific $\mathrm{CD}^{+}{ }^{+} \mathrm{T}$ cells from donor 4 using a synthetic M4I peptide. (A) Donor 4-derived $\mathrm{CD}^{+}{ }^{+} \mathrm{T}$ cells were primed with autologous DC pulsed with synthetic M4l peptide $\left(10 \mu \mathrm{g} \mathrm{ml} l^{-1}\right)$, but not rMAGE-A4 protein. The primed CD4 ${ }^{+}$T cells were stimulated with autologous PBMC pulsed with irrelevant peptide (open bar) or cognate peptide (filled bar) in the presence of $5 \mu \mathrm{g} \mathrm{ml}^{-1}$ of mAbs against HLA-DP, HLA-DQ or HLA-DR. (B) The M4I-specific Th cells were stimulated with allogeneic EBV-B-cell lines pulsed with irrelevant (open bar) or cognate (filled bar) peptide. All T-cell cultures were incubated with the MMC-treated target cells in duplicate for 20-24h, then the culture supernatants were assessed for IFN- $\gamma$ levels in ELISA. These experiments were carried out independently at least three times. Data denote mean \pm s.e.m. and are representative of the experiments.

APC, compared with the case that freshly isolated adherent cells were used. Surprisingly, the frequency of peptide-specific CD4 ${ }^{+}$ $\mathrm{T}$ cells primed with IFN- $\gamma$-treated adherent cells was almost the same as that primed with monocyte-derived DC. The generated Th cells produced much IFN- $\gamma$ and less IL- 4 in the presence of cognate peptide, indicating peptide-specific Th1 cells were dominantly activated in this condition (Figure 7B). We also showed that repetitive stimulation of Th1 cells with APC pulsed with MAGE-A4 helper epitope peptide resulted in 10-25-fold increase of the numbers of Th1 cells within a 28-day culture (Figure 8A). All the frequencies of helper (CD4-positive) $\mathrm{T}$ cells expanded were over 97\% (data not shown).

\section{Activation of MAGE-A4-specific Th1 cells with MAGE-A4 helper epitope peptide in the absence of APC}

The expanded CD4 ${ }^{+}$Th1 cells expressed MHC class II molecules and costimulatory molecules on their cell surface. Therefore, we tried whether MAGE-A4 helper epitope peptide could activate Th1 cells to produce IFN- $\gamma$ and IL-2 in the absence of APC. As shown in Figure $8 \mathrm{~B}$, addition of M41 peptide, but not irrelevant peptide to the samples resulted in the production of IFN- $\gamma$ and IL-2 from Th1 cells. Moreover, addition of M41 peptide to the mixed culture of Th1 cells and CD8 ${ }^{+} \mathrm{T}$ cells resulted in the induction of IFN- $\gamma$-producing $\mathrm{CD} 8{ }^{+} \mathrm{T}$ cells, which is preferable to induce Th1-dependent antitumour immunity (Figure 8C).

\section{DISCUSSION}

Recently, it has been indicated that $\mathrm{CD} 4{ }^{+}$Th cells play a crucial role in tumour immunology in addition to $\mathrm{CD} 8^{+}$CTL in both animal and human systems (Nishimura et al, 1999; Marzo et al, 2000; Ikeda et al, 2004; Janssen et al, 2005; Hunder et al, 2008). Indeed, in clinical study, our analysis of specimens from non-small cell lung carcinoma (NSCLC) showed significant correlations between infiltration of both $\mathrm{CD} 8{ }^{+}$and $\mathrm{CD} 4{ }^{+} \mathrm{T}$ cells into tumour nest and prognosis (Yoshida et al, 2006). Thus, it is important to develop the new immunotherapy, as using HLA class I and II-binding peptide-based vaccine (Odunsi et al, 2007) or antigen protein-based vaccine as activating both $\mathrm{CD} 8{ }^{+}$and $\mathrm{CD} 4{ }^{+}$effector T cells (Atanackovic et al, 2004; Uenaka et al, 2007). It has been, however, known that many regulatory $\mathrm{T}$ cells were induced in tumour-bearing hosts to inhibit effector function of CTL or Th cells (Liyanage et al, 2002). Therefore, it is difficult to activate these tumour-specific effector $\mathrm{T}$ cells under the suppressive condition in 
A
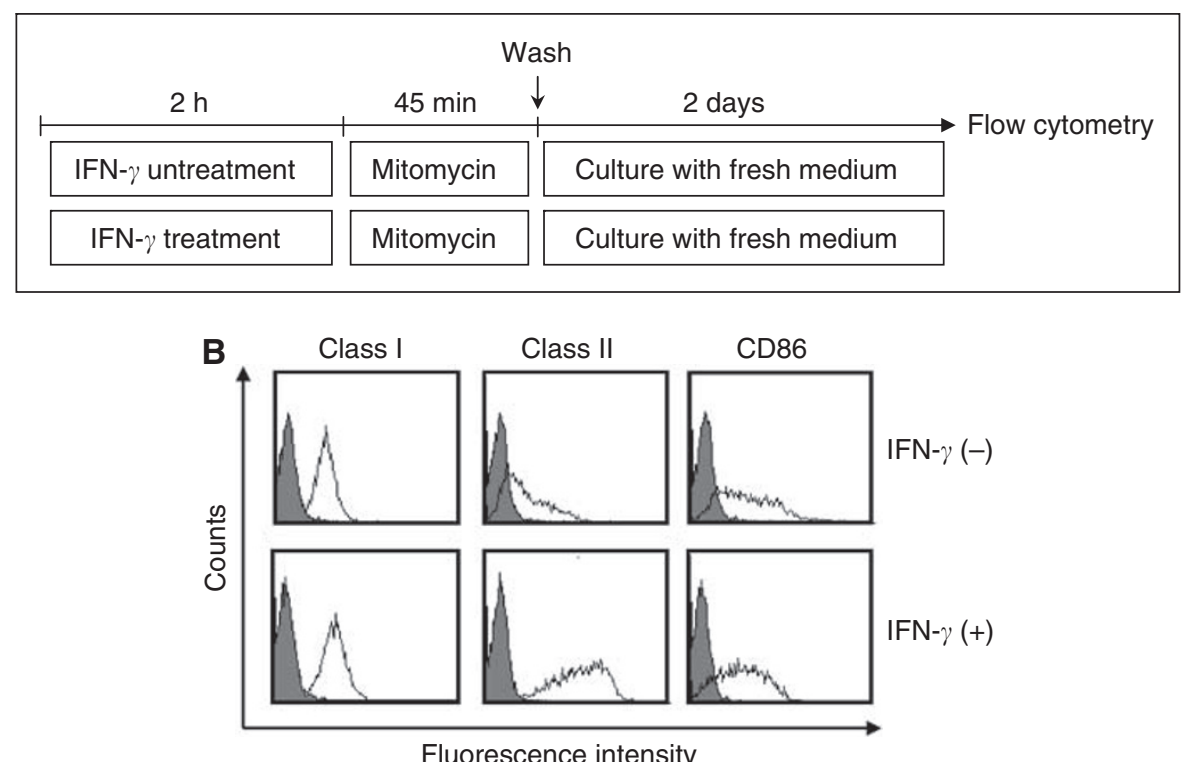

Figure 6 IFN- $\gamma$ treatment upregulated the expression of cell surface molecules on PBMC-derived adherent cells. (A) PBMC were incubated in the absence or presence of IFN- $\gamma\left(20 \mathrm{ng} \mathrm{ml}^{-1}\right)$ for $2 \mathrm{~h}$. After treatment of MMC, the adherent cells were incubated in fresh culture medium for 2 days. (B) For analysis of the expression of cell surface molecules on the cells, the cells were stained with anti-HLA class I, anti-HLA DP/DQ/DR, anti-human CD86 or control antibody for $15 \mathrm{~min}$, and analysed in a flow cytometry. These experiments were carried out independently at least three times. Data are representative of the experiments.

Table I IFN- $\gamma$ treatment upregulated the expression of cell surface molecules on PBMC-derived adherent cells

\begin{tabular}{|c|c|c|c|c|c|c|}
\hline \multirow{2}{*}{$\begin{array}{l}\text { Cell surface markers } \\
\text { IFN- } \gamma \text { treatment }\end{array}$} & \multicolumn{2}{|c|}{ HLA class I } & \multicolumn{2}{|c|}{ HLA class II } & \multicolumn{2}{|c|}{ CD86 } \\
\hline & $(-)$ & $(+)$ & $(-)$ & $(+)$ & $(-)$ & $(+)$ \\
\hline $\begin{array}{l}\text { Donor } 4 \\
\text { Donor } 5\end{array}$ & $\begin{array}{l}14.6^{\mathrm{a}} \\
22.4\end{array}$ & $\begin{array}{l}21.4 \\
37.6\end{array}$ & $\begin{array}{l}41.3 \\
210\end{array}$ & $\begin{array}{l}178 \\
688\end{array}$ & $\begin{array}{l}17.4 \\
21.2\end{array}$ & $\begin{array}{l}25.2 \\
35.3\end{array}$ \\
\hline
\end{tabular}

${ }^{a}$ Figures represent mean fluorescence intensity detected by flow cytometry.

a tumour-bearing host. To overcome the problem, we initially proposed the application of tumour-specific Th1 cells to adoptive tumour immunotherapy (Nishimura et al, 1999; Ikeda et al, 2004; Chamoto et al, 2006; Zhang et al, 2006). It has been well accepted that Th1-dominant immunity is critical for the successful induction of antitumour immunity in tumour-bearing hosts (Trinchieri, 2003 ). Our earlier study in animal models showed that the transfer of OVA-specific Th1 eradicated the transplanted OVA-expressing tumour. The spleen cells from mice treated with OVA-specific Th1 cells contained OVA-specific CTL, whereas OVA-specific Th2 cell therapy did not induced functional CTL (Nishimura et al, 1999). Moreover, by the combination therapy of OVA-specific TCR gene-modified Th1 cells with cyclophosphamide, OVA-expressing tumour was completely eradicated (Chamoto et al, 2004). In addition, in the transfer model of the gene-modified tumour-specific human $\mathrm{T}$ cells into immunodeficient mouse, combination treatment with tumour-specific Tc1 and Th1 completely rejected tumour, although tumourspecific Tcl alone did not show such an effect (Gyobu et al, 2004). These results suggest that Th1-cell therapy has the potential of enhancing antitumour immunity in patients with cancer. Therefore, we attempted to develop a protocol for the propagation of tumour-specific human Th1 cells in vitro. The choice of targeted tumour antigen is of importance in the conduct of clinical trials of tumour immunotherapy. MAGE-A4 is an attractive antigen because of its wide expression in a variety of tumours and its immunogenicity (Tajima et al, 2003; Yakirevich et al, 2003; Lin et al, 2004; Prasad et al, 2004; Li et al, 2005). Earlier studies reported the generation of MAGE-A4-specific CTL clones and definition of its epitope peptides (Zhang et al, 2002; Miyahara et al, 2005). However, no helper epitopes of MAGE-A4 have been reported. In this study, we first identified the helper epitope peptides derived from MAGE-A4, which are presented to $\mathrm{DPB} 1{ }^{\star} 0501$ and $\mathrm{DRB} 1{ }^{\star} 1403$, indicating that this tumour peptide is a promiscuous peptide (Figure 4). In several tumour antigens, promiscuous peptides have been identified (Kobayashi et al, 2000; Ohkuri et al, 2007). Binding ability of these peptides to multiple HLA could overcome the limitation of HLA restriction of cancer patients. In addition, as DPB $1{ }^{\star} 0501$, which M41 peptide binds to, is frequently expressed in Japanese population (approximately $60 \%)$, it is expected that our defined helper peptide would contribute to the tumour immunotherapy of patients with MAGEA4-expressing tumour.

In this study, we established a protocol for the efficient induction and propagation of peptide-specific Th1 cells. In most of adoptive cell therapy so far performed, the injected cells were mainly expanded from TIL by culturing with anti-CD3 mAb and high-dose IL-2 (Dudley et al, 2001, 2005). As it is difficult to obtain TIL from each patient, the strategy has a limitation. To overcome this limitation, Morgan et al (2006) developed the approach to therapy based on the genetic modification of PBMC. They reported that transfer of tumour antigen-specific TCR gene-modified PBL enhanced antitumour immunity in the patients. Moreover, Labarriere et al (2008) recently reported that PBMCs were good sources of CTL as well as TIL. In fact, they had performed adoptive cell therapy in clinical trial, in which PBMC-derived CTL clones were used (Vignard et al, 2005). Likewise, our strategy is that PBMCs are used as sources of $\mathrm{CD} 4^{+} \mathrm{T}$-cell for generating tumourspecific Th cells. In addition, we used PBMC-derived adherent cells as antigen-presenting cells. This strategy has the advantage that it does not take a long time from collection of blood to the initiation of $\mathrm{CD}^{+}{ }^{+}$T-cell sensitisation. Although freshly isolated PBMCderived adherent cells had less stimulatory activity, IFN- $\gamma$-treated adherent cells showed the upregulated expression of MHC class II and CD86 costimulatory molecules to acquire stimulatory activity 
A

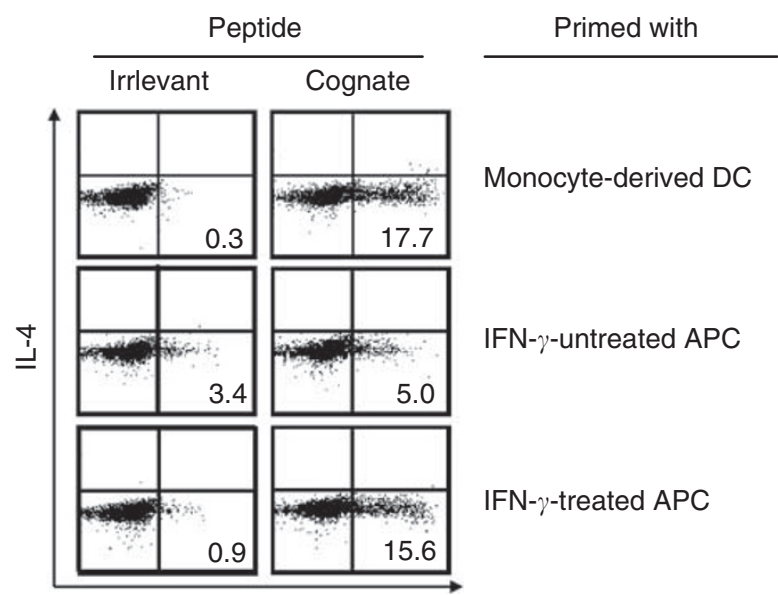

IFN- $\gamma$
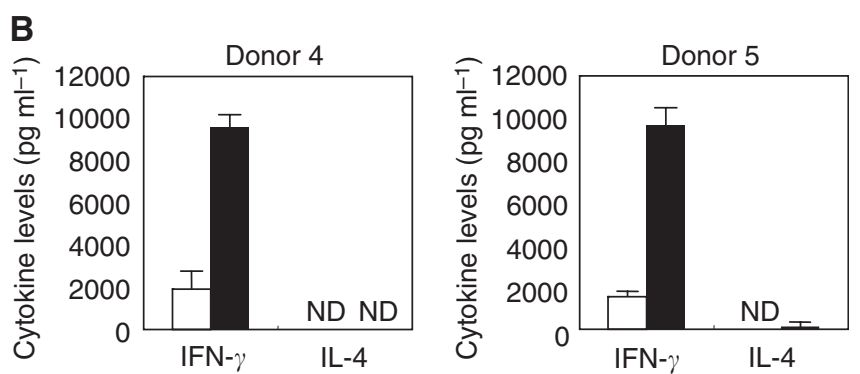

Figure 7 Efficient inductions of MAGE-A4-specific CD4 ${ }^{+} \mathrm{T}$ cells primed with IFN- $\gamma$-treated adherent cells. (A) $\mathrm{CD}^{+}{ }^{+} \mathrm{T}$ cells were primed with monocyte-derived DC, IFN- $\gamma$-untreated APC or IFN- $\gamma$-treated APC in the presence of $10 \mu \mathrm{g} \mathrm{ml}^{-1} \mathrm{M} 4 \mathrm{l}$ peptide. Specific responses of each CD4 ${ }^{+}$ $T$ cells were assessed in an intracellular staining assay with PE-conjugated anti-IL-4 mAb and FITC-conjugated anti-IFN- $\gamma$ mAb. Numbers represents percentages of IFN- $\gamma$-producing cells in $\mathrm{CD}^{+}{ }^{+} \mathrm{T}$ cells. Data are representative of three independent experiments. (B) $\mathrm{CD}^{+}{ }^{+} \mathrm{T}$ cells from donors 4 and 5 primed with IFN- $\gamma$-treated adherent cells were assessed their cytokine production profiles in ELISA. ND= not detected. These experiments were carried out independently at least three times. Data denote mean \pm s.e.m. and are representative of the experiments.

as well as monocyte-derived DC (Figure 6B and Table 1). Moreover, the expanded MAGE-A4-specific Th cells produced high levels of IFN- $\gamma$ and less IL-4 in two healthy donors tested, suggested that the Th cells would differentiate into Th1 cells (Figure 7B). Moreover, the Th cells produced neither IL-10 nor IL-17, and did not detect Foxp3 expression (data not shown). Therefore, our developed method may be beneficial to apply adoptive Th1 cell therapy to clinical study.

Finally, as shown in Figure 8B, we also showed that MAGE-A4 helper epitope peptides were presented to MHC class II molecules on MAGE-A4-specific Th1 cells to stimulate Th1-derived cytokine release, which is preferable to induce IFN- $\gamma$-producing Tc1 cells essential for eradication of tumour cells.

In conclusion, we first identified MAGE-A4-derived helper peptides, which will become a good tool for propagating and activating MAGE-A4 peptide-specific Th1 cells. These findings would contribute to a clinical trial of adoptive Th1-cell therapy against MAGE-A4-expressing human cancer in future. Recently, Hunder et al (2008) reported that NY-ESO-1-specific CD4 ${ }^{+} \mathrm{T}$ cells into patients with metastatic melanoma caused a great inhibition of tumour. The new challenge to the adoptive immunotherapy is now started and we believed that Th1-cell therapy using tumourspecific Th1 cells expanded with helper epitope peptide would become a promising strategy for the immunotherapy of human cancer.
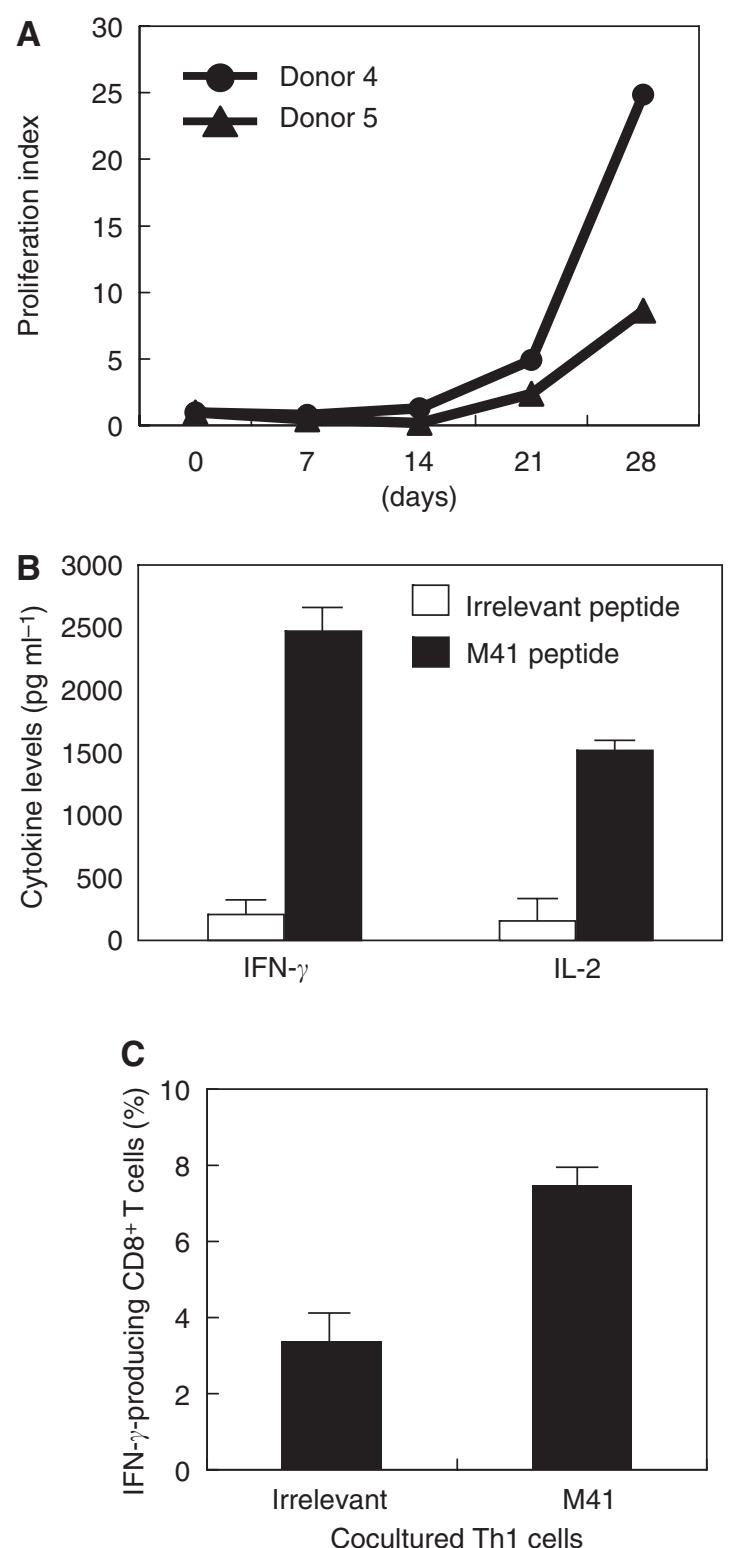

Figure 8 The number of MAGE-A4-specific ThI cells increased in vitro culture and the expanded ThI cells were activated in the presence of the cognate peptide without APC. (A) CD4 ${ }^{+} \mathrm{T}$ cells from donors 4 and 5 were stimulated with APC pulsed with MAGE-A4-helper epitope peptide weekly. At days $0,7,14,21$ and 28 , the cultured $T$ cells were collected and the total cell number was counted. The growth rates compared with number at day 0 were displayed. (B) In the absence of APC, MAGE-A4speficific ThI cells were cultured with irrelevant (open bar) or cognate (filled bar) peptide $\left(10 \mu \mathrm{g} \mathrm{ml}^{-1}\right)$ for $24 \mathrm{~h}$. The culture supernatants were collected and assessed cytokine levels in ELISA. (C) In the absence of APC, the ThI cells were cultured with autologous $C D 8^{+} \mathrm{T}$ cells in the presence of control (irrelevant) or cognate (M4I) peptide $\left(10 \mu \mathrm{g} \mathrm{ml}^{-1}\right)$. At day 5 , IFN- $\gamma$-producing $C D 8^{+} T$ cells in stimulating with anti-CD3 mAb were assessed by intracellular staining using PE-conjugated anti-CD8 mAb and FITC-conjugated anti- IFN- $\gamma$ mAb. These experiments were carried out independently at least three times. Data denote mean \pm s.e.m. and are representative of the experiments.

\section{ACKNOWLEDGEMENTS}

We thank Takuko Sawada (Shionogi Pharmaceutical Institute Co., Osaka, Japan) for kindly donations of recombinant IL-2. This study was supported in part by Grant-in-Aid for Scientific Research on priority Areas, a Cancer Translational Research 
Project, and a National Project 'Knowledge Cluster Initiative' (2nd stage, 'Sapporo Biocluster Bio-S') from the Ministry of Education,
Culture, Sports, Science and Technology, Japan (MEXT), and by a JSPS Research Fellowship for Young Scientists (TO).

\section{REFERENCES}

Atanackovic D, Altorki NK, Stockert E, Williamson B, Jungbluth AA, Ritter E, Santiago D, Ferrara CA, Matsuo M, Selvakumar A, Dupont B, Chen YT, Hoffman EW, Ritter G, Old LJ, Gnjatic S (2004) Vaccineinduced CD4+ $\mathrm{T}$ cell responses to MAGE-3 protein in lung cancer patients. J Immunol 172: 3289-3296

Bennett SR, Carbone FR, Karamalis F, Flavell RA, Miller JF, Heath WR (1998) Help for cytotoxic-T-cell response is mediated by CD40 signaling. Nature 393: $478-480$

Buelens C, Bartholome EJ, Amaraoui Z, Boutriaux M, Salmon I, Thielemans K, Willems F, Goldman M (2002) Interleukin-3 and interferon beta cooperate to induce differentiation of monocytes into dendritic cells with potent helper T-cell stimulatory properties. Blood 99: 993-998

Chamoto K, Kosaka A, Tsuji T, Matsuzaki J, Sato T, Takeshima T, Iwakabe K, Togashi Y, Koda T, Nishimura T (2003) Critical role of the Th1/Tc1 circuit for the generation of tumor-specific CTL during tumor eradication in vivo by Th1-cell therapy. Cancer Sci 94: 924-928

Chamoto K, Wakita D, Narita Y, Zhang Y, Noguchi D, Ohnishi H, Iguchi T, Sakai T, Ikeda H, Nishimura T (2006) An essential role of antigenpresenting cell/T-helper type 1 cell-cell interactions in draining lymph node during complete eradication of class II-negative tumor tissue by T-helper type 1 cell therapy. Cancer Res 66: 1809-1817

Chamoto K, Tsuji T, Funamoto H, Kosaka A, Matsuzaki J, Sato T, Abe H, Fujio K, Yamamoto K, Kitamura T, Takeshima T, Togashi Y, Nishimura $\mathrm{T}$ (2004) Potentiation of tumor eradication by adoptive immunotherapy with T-cell receptor gene-transduced T-helper type 1 cells. Cancer Res 64: $386-390$

Chomez P, De Backer O, Bertrand M, De Plaen E, Boon T, Lucas S (2001) An overview of the MAGE gene family with the identification of all human members of the family. Cancer Res 61: 5544-5551

De Plaen E, Arden K, Traversari C, Gaforio JJ, Szikora JP, De Smet C, Brasseur F, Van der Bruggen P, Lethe B, Lurquin C, Brasseur R, Chomez P, De Backer O, Cavenee W, Boon T (1994) Structure, chromosomal localization, and expression of 12 genes of the MAGE family. Immunogenetics 40: $360-369$

Dudley ME, Wunderlich J, Nishimura MI, Yu D, Yang JC, Topalian SL, Schwartzentruber DJ, Hwu P, Marincola FM, Sherry R, Leitman SF, Rosenberg SA (2001) Adoptive transfer of cloned melanoma-reactive $T$ lymphocytes for the treatment of patients with metastatic melanoma. Immunother 24: $363-373$

Dudley ME, Wunderlich JR, Robbins PF, Yang JC, Hwu P, Schwartzentruber DJ, Topalian SL, Sherry R, Restifo NP, Hubicki AM, Robinson MR Raffeld M, Duray P, Seipp CA, Rogers-Freezer L, Morton KE, Mavroukakis SA, White DE, Rosenberg SA (2002a) Cancer regression and autoimmunity in patients after clonal repopulation with antitumor lymphocytes. Science 298: $850-854$

Dudley ME, Wunderlich JR, Yang JC, Hwu P, Schwartzentruber DJ, Topalian SL, Sherry RM, Marincola FM, Leitman SF, Seipp CA, RogersFreezer L, Morton KE, Nahvi A, Mavroukakis SA, White DE, Rosenberg SA (2002b) A phase I study of nonmyeloablative chemotherapy and adoptive transfer of autologous tumor antigen-specific $\mathrm{T}$ lymphocytes in patients with metastatic melanoma. J Immunother 25: 243-251

Dudley ME, Wunderlich J, Yang JC, Sherry RM, Topalian SL, Restifo NP, Royal RE, Kammula U, White DE, Mavroukakis SA, Rogers LJ, Gracia GJ, Jones SA, Mangiameli DP, Pelletier MM, Gea-Banacloche J, Robinson MR, Berman DM, Filie AC, Abati A, Rosenberg SA (2005) Adoptive cell transfer therapy following non-myeloablative but lymphodepleting chemotherapy for the treatment of patients with refractory metastatic melanoma. J Clin Oncol 23: 2346-2357

Giuntoli II RL, Lu J, Kobayashi H, Kennedy R, Celis E (2002) Direct costimulation of tumor-reactive CTL by helper $\mathrm{T}$ cells potentiates their proliferation, survival, and effector function. Clin Cancer Res 8: 922-931

Gyobu H, Tsuji T, Suzuki Y, Ohkuri T, Chamoto K, Kuroki M, Miyoshi H, Kawarada Y, Katoh H, Takeshima T, Nishimura T (2004) Generation and targeting of human tumor-specific $\mathrm{Tc} 1$ and $\mathrm{Th} 1$ cells transduced with a lentivirus containing a chimeric immunoglobulin T-cell receptor. Cancer Res 64: $1490-1495$
Hunder NN, Wallen H, Cao J, Hendricks DW, Reilly JZ, Rodmyre R, Jungbluth A, Gnjatic S, Thompson JA, Yee C (2008) Treatment of metastatic of metastatic melanoma with autologous CD4+ $\mathrm{T}$ cells against NY-ESO-1. N Engl J Med 358: $2698-2703$

Ikeda H, Chamoto K, Tsuji T, Suzuki Y, Wakita D, Takeshima T, Nishimura $\mathrm{T}$ (2004) The critical role of type-1 innate and acquired immunity in tumor immunotherapy. Cancer Sci 95: 697-703

Janssen EM, Droin NM, Lemmens EE, Pinkoski MJ, Bensinger SJ, Ehst BD, Griffith TS, Green DR, Schoenberger SP (2005) CD4+ T-cell help controls CD8+ T-cell memory via TRAIL-mediated activation-induced cell death. Nature 434: 88-93

Janssen EM, Lemmens EE, Wolfe T, Christen U, von Herrath MG, Schoenberger SP (2003) $\mathrm{CD}^{+} \mathrm{T}$ cells are required for secondary expansion and memory in $\mathrm{CD}^{+} \mathrm{T}$ lymphocytes. Nature 421: $852-856$

Kobayashi H, Celis E (2008) Peptide epitope identification for tumorreactive CD4 $\mathrm{T}$ cells. Curr Opin Immunol 20: $221-227$

Kobayashi H, Wood M, Song Y, Appella E, Celis E (2000) Defining promiscuous MHC class II helper T-cell epitopes for the HER2/neu tumor antigen. Cacncer Res 60: 5228-5236

Labarriere N, Gervois N, Bonnin A, Bouquie R, Jotereau F, Lang F (2008) PBMC are as good a source of tumor-reactive T lymphocytes as TIL after selection by Melan-A/A2 multimer immunomagnetic sorting. Cancer Immunol Immunother 57: 185-195

Li M, Yuan Y-H, Han Y, Liu YX, Yan L, Wang Y, Gu J (2005) Expression profile of cancer-testis genes in 121 human colorectal cancer tissue and adjacent normal tissue. Clin Cancer Res 11: 1809-1814

Lin J, Lin L, Thomas DG, Greenson JK, Gioradano TJ, Robinson GS, Barve RA, Weishaar FA, Taylor JM, Orringer MB, Beer DG (2004) Melanoma-associated antigens in esophageal adenocarcinoma: identification of novel MAGE-A10 splice variants. Clin Cancer Res 10: $5708-5716$

Liyanage UK, Moore TT, Joo HG, Tanaka Y, Herrmann V, Doherty G, Drebin JA, Strasberg SM, Eberlein TJ, Goedegebuure PS, Linehan DC (2002) Prevalence of regulatory T cells is increased in peripheral blood and tumor microenvironment of patients with pancreas or breast adenocarcinoma. J Immunol 169: 2756-2761

Lu Z, Yuan L, Zhou X, Sotomayor E, Levitsky HI, Pardoll DM (2000) CD40independent pathways of $\mathrm{T}$ cell help for priming of CD8+ cytotoxic $\mathrm{T}$ lymphocytes. J Exp Med 191: 541-550

Marzo AL, Kinnear BF, Lake RA, Frelinger JJ, Collins EJ, Robinson BW, Scott B (2000) Tumor-specific CD4+ T cells have a major 'post-licensing' role in CTL mediated anti-tumor immunity. J Immunol 165: $6047-6055$

Miyahara Y, Naota H, Wang L, Hiasa A, Goto M, Watanabe M, Kitano S, Okumura S, Takemitsu T, Yuta A, Majima Y, Lemonnier FA, Boon T, Shiku H (2005) Determination of cellularly processed HLA-A2402restricted novel CTL epitopes derived from two cancer germ line genes, MAGE-A4 and SAGE. Clin Cancer Res 15: 5581-5589

Morgan RA, Dudley ME, John R, Wunderlich JR, Hughes MS, Yang JC, Sherry RM, Royal RE, Topalian SL, Kammula US, Restifo NP, Zheng Z, Nahvi A, de Vries CR, Rogers-Freezer LJ, Mavroukakis SA, Rosengerg SA (2006) Cancer regression in patients after transfer of genetically engineered lymphocytes. Science 314: 126-129

Nishimura T, Iwakabe K, Sekimoto M, Ohmi Y, Yahata T, Nakui M, Sato T, Habu S, Tashiro H, Sato M, Ohta A (1999) Distinct role of antigenspecific T helper type 1 (Th1) and Th2 cells in tumor eradication in vivo. J Exp Med 190: 617-627

Odunsi K, Qian F, Matsuzaki J, Mhawech-Fauceglia P, Andrews C, Hoffman EW, Pan L, Ritter G, Villella J, Thomas B, Rodabaugh K, Lele S, Shrikant P, Old LJ, Gnjatic S (2007) Vaccination with an NY-ESO-1 peptide of HLA class I/II specificities induces integrated humoral and $\mathrm{T}$ cell responses in ovarian cancer. Proc Natl Acad Sci USA 104: 12837-12842

Ohkuri T, Sato M, Abe H, Tsuji K, Yamagishi Y, Ikeda H, Matsubara N, Kitamura H, Nishimura T (2007) Identification of a novel NY-ESO-1 promiscuous helper epitope presented by multiple MHC class II molecules found frequently in the Japanese population. Cancer Sci 98: $1092-1098$ 
Prasad ML, Jungbluth AA, Patel SG, Iversen K, Hoshaw-Woodard S, Busam K (2004) Expression and significance of cancer testis antigen in primary mucosal melanoma of the head and neck. Head Neck 26: 1053 - 1057

Sato M, Iwakabe K, Kimura S, Nishimura T (1999) Functional skewing of bone marrow-derived dendritic cells by Th1- or Th2-inducing cytokines. Immunol Lett 67: 63-68

Schoenbergner SP, Toes RE, van der Voort EI, Offringa R, Melief CJ (1998) T-cell help for cytotoxic T lymphocytes is mediated by CD40-CD40L interactions. Nature 393: $480-483$

Smith CM, Wilson NS, Waithman J, Villadangos JA, Carbone FR, Heath WR, Bertz GT (2004) Cognate CD4 (+) T cell licensing of dendritic cells in CD8 (+) T cell immunity. Nat Immunol 5: 1143-1148

Sun JC, Williams MA, Bevan MJ (2004) $\mathrm{CD}^{+} \mathrm{T}$ cells are required for the maintenance, not programming, of memory $\mathrm{CD}^{+} \mathrm{T}$ cells after acute infection. Nat Immunol 5: 927-933

Tajima K, Obata Y, Tamaki H, Yoshida M, Chen YT, Scanlan MJ, Old LJ, Kuwano H, Takahashi T, Takahashi T, Mitsudomi T (2003) Expression of cancer/testis (CT) antigens in lung cancer. Lung Cancer 42: 23-33

Trinchieri G (2003) Interleukin-12 and the regulation of innate resistance and adaptive immunity. Nat Rev Immunol 3: 133 - 146

Uenaka A, Wada H, Isobe M, Saika T, Tsuji K, Sato E, Sato S, Noguchi Y, Kawabata R, Yasuda T, Doki Y, Kumon H, Iwatsuki K, Shiku H, Monden M, Jungbluth AA, Ritter G, Murphy R, Hoffman E, Old LJ, Nakayama E (2007) T cell immunomonitoring and tumor responses in patients immunized with a complex of cholesterol bearing hydrophobized pullulan (CHP) and NY-ESO-1 protein. Cancer Immun 7: 9

Van der Bruggen P, Traversari C, Chomez P, Lurquin C, De Plaen E, Van den Eynde B, Knuth A, Boon T (1991) A gene encoding an antigen recognized by cytotoxic $\mathrm{T}$ lymphocytes on a human melanoma. Science 254: $1643-1647$

Vignard V, Lemercier B, Lim A, Pandolfino MC, Guilloux Y, Khammari A, Rabu C, Echasserieau K, Lang F, Gougeon ML, Dreno B, Jotereau F, Labarriere N (2005) Adoptive transfer of tumor-reactive Melan-A-specific CTL clones in melanoma patients is follwed by increased frequencies of additional Melan-A-specific T cells. J Immunol 175: 4797-4805

Yakirevich E, Sabo E, Lavie O, Mazareb S, Spagnoli GC, Resnick M (2003) Expression of the MAGE-A4 and NY-ESO-1 cancertestis antigens in serous ovarian neoplasms. Clin Cancer Res 9: 6453-6460

Yoshida N, Abe H, Ohkuri T, Wakita D, Sato M, Noguchi D, Miyamoto M, Morikawa T, Kondo S, Ikeda H, Nishimura T (2006) Expression of the MAGE-A4 and NY-ESO-1 cancer-testis antigens and T cell infiltration in non-small cell lung cartinoma and their prognostic significance. Int $J$ Oncol 28: 1089 - 1098

Zhang Y, Wakita D, Chamoto K, Narita Y, Matsubara N, Kitamura H, Nishimura T (2006) Th1 cell adjuvant therapy combined with tumor vaccination: a novel strategy for promoting CTL responses while avoiding the accumulation of Tregs. Int Immunol 19: 151-161

Zhang Y, Stroobant V, Russo V, Boon T, Van der Bruggen P (2002) A MAGE-A4 peptide presented by HLA-B37 is recognized on human tumors by cytolytic T lymphocytes. Tissue Antigens 60: 365-371 